\title{
Endoesophageal Brachytherapy
}

National Cancer Institute

\section{Source}

National Cancer Institute. Endoesophageal Brachytherapy. NCI Thesaurus. Code C154606.

The use of localized, internal radiation therapy for the treatment of esophageal cancer. 